\title{
Implementasi pembelajaran tematik pada pendidikan anak usia dini
}

\author{
Kartini Kartini *, Waridah Waridah \\ Program Studi Pendidikan Guru Pendidikan Anak Usia Dini, Sekolah Tinggi Keguruan dan \\ Ilmu Pendidikan Melawi. Jalan RSUD Melawi, KM o4 Nanga Pinoh, Kab. Melawi, Indonesia \\ * Corresponding Author. E-mail: kartini.lombok88@gmail.com \\ Received: 8 November 2018; Revised: 10 December 2018; Accepted: 21 December 2018
}

\begin{abstract}
Abstrak
Tujuan penelitian ini adalah untuk mengetahui: (1) Perencanaan pembelajaran tematik (2) Pelaksanaan pembelajaran tematik, dan (3) Evaluasi pembelajaran tematik di PAUD Kabupaten Melawi. Teknik pegumpulan data digunakan dengan berbagai setting alamiah yaitu di lembaga dengan pengelola, pendidik, dan peserta didik PAUD di Melawi. Teknik pengumpulan data dalam penelitian meliputi; observasi, wawancara, dan triangulasi. Teknik analisis dalam penelitian melalui keabsahan data dan pemeriksaan, pemeriksaan data dalam penelitian mengikuti kriteria yang sudah ditetapkan yaitu; Kepercayaan (credibility), Keteralihan (transferability), Kebergantungan (depandability), dan Kepastian (confirmability). Hasil penelitian menunjukan bahwa PAUD di Kabupaten Melawi mengimplemntasikan pembelajaran tematik sudah cukup baik.Hal ini dapat dilihat dalam penyusunan perangkat pembelajaran (Porta, Porsem, RPPM dan RPPH), selain itu penerapan pembelajaran tematik sudah sesusi dengan rinsip-prinsip tematik.
\end{abstract}

Kata Kunci: implementasi, pembelajaran tematik, pendidikan anak usia dini

\section{Implementation thematic learning early childhood education}

\section{Abstract}

The purpose of this research is (1) planning thematic learning (2) implementation of thematic learning, and (3) evaluation of thematic learning in Early Age Education Center Melawi. Data collection techniques are used with a variety of natural settings i.e. in institutions with managers, educators, and learners of Early Age Education Center in Melawi. Data collection techniques in the research include; observation, interview, and triangulation. Analysis techniques in the research through the validity of data and examination, the examination of the data in the study follow the criteria already set namely; Trust (credibility), transfer (transferability), Reliance (dependability), and Assurance (conformability). The result of this research is theEarly Age Education Center and implementing thematic Study is already good enough. This can be seen in the preparation oflearning devices (Porta, Porsem, RPPM and RPPH), besides that, the application of thematic learning has been consistent with thematic principles.

Keywords: early childhood education, implementation, thematic learning

How to Cite: Kartini, K., \& Waridah, W. (2018). Implementasi pembelajaran tematik pada pendidikan anak usia dini. JPPM (Jurnal Pendidikan dan Pemberdayaan Masyarakat), 5(2), 191-201. doi:https://doi.org/10.21831/jppm.v5i2.23132

https://doi.org/10.21831/jppm.v5i2.23132

\section{PENDAHULUAN}

Pendidikan Anak Usia Dini (PAUD) merupakan pendidikan yang paling funda- mental karena perkembangan anak di masa selanjutnya akan sangat ditentukan oleh berbagai stimulasi bermakna yang diberikan 
sejak usia dini (Essa, 2011). Awal kehidupan anak merupakan masa yang paling tepat dalam memberikan dorongan atau upaya pengembangan agar anak dapat berkembang secara optimal. Undang Undang Nomor 20 Tahun 2003 tentang Sistem Pendidikan Nasional Bab I Pasal 1 butir 14 menyatakan bahwa PAUD merupakan suatu upaya pembinaan yang ditujukan kepada anak sejak lahir sampai dengan usia 6 tahun yang dilakukan melalui rangsangan pendidikan untuk membantu pertumbuhan dan perkembangan jasmani dan rohani agar anak memiliki kesiapan belajar dalam memasuki pendidikan lebih lanjut. Undang-undang Nomor 20 tahun 2003 tentang Sistem Pendidikan Nasional menyebutkan bahwa kurikulum adalah seperangkat rencana dan pengaturan mengenai tujuan, isi, dan bahan pelajaran serta cara yang digunakan sebagai pedoman penyelenggaraan kegiatan pembelajaran untuk mencapai tujuan pendidikan tertentu. Berdasarkan pengertian tersebut, terdapat dua dimensi kurikulum. Dimensi pertama adalah rencana dan pengaturan mengenai tujuan, isi, dan bahan pelajaran, sedangkan yang kedua adalah cara yang digunakan untuk kegiatan pembelajaran (Presiden Republik Indonesia, 2003).

Kurikulum 2013 disusun untuk mengembangkan dan memperkuat sikap, pengetahuan, dan keterampilan secara berimbang. Kebijakan Kurikulum 2013 menyangkut empat elemen perubahan kurikulum yaitu pada Standar Kelulusan (SKL), Standar Isi (SI, Standar Proses, dan Standar Penilaian, Sistem pembelajaran dalam perubahan Kurikulum 2013 berdampak empat hal, yaitu model pembelajaran tematik-integratif, pendekatan saintifik, strategi aktif, dan penilaian autentik. Dari hasil kajian tersebut dapat diketahui bahwa penelitian yang telah dilakukan sebelumnya oleh (Machali, 2014, p. 8; Sari, Baharuddin, \& Sasmiati, 2015) menunjukkan bahwa implementasi kurikulum dalam jenjang pendidikan dasar menengah serta pendidikan tinggi sangat baik.

Pembelajaran tematik telah dilaksanakan oleh beberapa PAUD yang ada di Kabupaten Melawi. Dalam pelaksanaan pembelajaran tematik yang digunakan mengambil dari panduan yang dibuat oleh GOPTKI
Kabupaten Melawi. Sehingga dalam penggunaan tema-tema pembelajaran guru dan anak menyesuaikan yang sudah ada. Sedangkan dalam membuat tema-tema pembelajaran ada beberapa prinsip pembelajaran tematik yang harus dilakukan.

Penentuan tema sangat terbuka, artinya, satuan PAUD dapat menentukan tema yang akan digunakan dalam pembelajaran sesuai dengan minat anak, situasi dan kondisi lingkungan, serta kesiapan guru mengelola kegiatan. Penentuan tema tidak sekadar mudah diterapkan, tetapi perlu memperhatikan beberapa prinsip agar pembelajaran yang dilaksanakan lebih menarik dan mendalam. Keluasan tema bergantung pada kemampuan guru dalam menguasai tema tersebut. Hal penting yang harus diperhatikan guru dalam mengembangkan tema adalah kebermaknaan tema dalam membangun pengalaman belajar yang bermutu bagi anak usia dini. Oleh karena itu dalam menentukan tema menjadi penting bila diawali dengan identifikasi tema dan sekaligus ketertarikan anak terhadap topik tertentu.

Hal ini yang membuat peneliti menarik untuk mengadakan penelitian implementasi pembelajaran tematik di PAUD Kabupaten Melawi, pembelajaran tematik yang diterapkan selama ini sudah sesuai dengan prinsipprinsip pembelajaran tematik di PAUD. Berdasarkan latar belakang masalah tersebut, tujuan penelitian ini yaitu untuk mengetahui perencanaan, pelaksanaan, dan penilaian pembelajaran tematik di PAUD Kabupaten Melawi.

\section{METODE}

Bentuk penelitian yang dilakukan dalam penelitian ini yaitu kualitatif dengan pendekatan studi kasus. Dalam penelitian kualitatif ini menghasilkan data deskriptif berupa kata-kata tertulis, lisan serta mengali informasi sebanyak mungkin pada permasalahan dari implementasi pembelajaran tematik. Hal ini sejalan dengan pendapat (Moleong, 2013, p. 3) studi kasus merupakan penelitian dimana peneliti menggali suatu fenomena tertentu (kasus) dalam suatu waktu dan kegiatan serta mengumpulkan informasi soecara terinci dan mendalam dengan menggunakan berbagai prosedur pengum- 
JPPM (Jurnal Pendidikan dan Pemberdayaan Masyarakat), 5 (2), 2018 - 193

Kartini Kartini, Waridah Waridah

pulan data selama periode tertentu. Studi kasus terkadang dapat juga dipergunakan untuk menyelidiki unit sosial yang kecil seperti keluarga, sekolah, dan kelompokkelompok tertentu (Idrus, 2009). Sedangkan menurut (Merriam \& Tisdell, 2015, p. 40) mendefinisikan studi kasus adalah sebagai berikut: A case study in-depth description an analysis something of a bounded system. Part of the confusion surrounding case study is that the process of conducting a case study is conflacted with both the unit of study (the case) and the product of this type of investigation.

Berdasarkan uraian tentang studi kasus dan implementasinya, maka pendekatan studi kasus dalam penelitian ini akan dilaksanakan pada suatu unit sosial lembaga atau single-case study (studi kasus tunggal) yaitu pada lembaga PAUD di Kabupaten Melawi. Alasan dipilihnya lembaga PAUD di Kabupaten Melawi sebagai tempat lokasi penelitian karena proses pembelajaran di lembaga tersebut telah menerapkan pembelajaran tematik dan bisa dijadikan percontohan bagi lembaga PAUD lainnya. Waktu penelitian dilakukan selama 9 bulan terhitung sejak Februari sampai dengan November 2018.

Subjek peneltian ini adalah pengelola, pendidik, dan peserta didik atau semua komponen yang ikut terlibat dalam proses kegiatan belajar pada pendidikan anak usia dini di Kabupaten Melawi. Dalam penelitian ini instrumen utama yang digunakan adalah diri peneliti, oleh karena itu peneliti harus menguasai materi tentang cara melengkapi, mengolah dan menganalisis data dari hasil observasi, wawancara dan dokumentasi. Dalam penelitian kualitatif kunci keberhasilan dalam penelitian adalah kualitas instrumen yaitu peneliti sendiri. Selain instrumen dari peneliti, pengumpulan data juga dilakukan berdasarkan:

Teknik observasi untuk mengamati dan mendeskripsikan aktivitas belajar yang ada di PAUD Kabupaten Melawi yang meliputi:aktivitas belajar, aktivitas peserta didik, aktivitas bermain, lingkungan belajara, serta sarana dan prasarana yan dimiliki PAUD tersebut. Selain itu, Observasi dilakukan untuk mengetahui data dan fakta tentang implementasi pembelajaran tematik di PAUD Kabupaten
Melawi yang meliputi perencanaan, pelaksanaan dan evaluasi pembelajaran tematik di PAUD Melawi. Jenis observasi yang digunakan yaitu observasi partisipatif. Observasi partisipatif merupakan obeservasi yang melibatkan peneliti dengan kegiatan sehari-hari obyek yang diteliti dalam penelitian (Sugiyono, 2015, p. 310).

Teknik wawancara kegiatan percakapan dengan maksud tertentu, yang dilakukan oleh dua belah pihak yaitu pewawancara dan yang diwawancarai. Dalam penelitian ini, wawancara dilakukan oleh peneliti sebagai proses komunikasi atau interaksi untuk mengumpulkan informasi yang mendalam tentang pembelajaran tematik di PAUD Melawi dengan cara tanya jawab kepada informan atau subjek penelitian. Selain itu, wawancara juga merupakan alat re-checking atau pembuktian peneliti terhadap informasi atau keterangan yang diperoleh sebelumnya. Teknik wawancara menggali informasi dari pengelola/penyelenggara dan pendidik yang ada di PAUD Kabupaten Melawi Terkait program khusus serta studi pustaka untuk mendapatkan kajian informasi seputar implementasi pembelajaran tematik di PAUD Kabupaten Melawi.

Dokumentasi digunakan untuk memperoleh data dari lembaga PAUD yang ada di Kabupaten Mealwi meliputi: (1) Dokumentasi data proses kegiatan belajar peserta didik, data hasil karya anak, data struktur kelembagaan serta data pendidik, (2) Dokumentasi data kelengkapan perangkat pembelajaran (Program Tahunan, Program Semester, Rancangan Pelaksanaan Pembelajaran Mingguan dan Rancangan Pelaksanaan Pembelajaran Harian).

Triangulasi dalam teknik pengumpulan data diartikan teknik pengumpulan data yang bersifat menggabungkan dari berbagai teknik pengumpulan data dan sumber yang telah ada. Tujuan dari triangulasi tidak untuk mencari kebenaran tentang beberapa fenomena, tetapi lebih pada peningkatan pemahaman peneliti terhadap apa yang telah ditemukan. Hal-hal yang dilakukan dalam triangulasi data sebagai berikut: (1) Membandingkan data hasil pengamatan dengan data hasil wawancara; (2) Membandingkan hasil wawancara dengan isi dokumentasi yang berkaitan; 
(3) Membandingkan hasil wawancara dengan sumber yang berbeda; dan (4) Menafsirkan data kemudian mengambil kesimpulan.

Keabsahan data dalam penelitian ini mengikuti kriteria dari (Moleong, 2013, p. 324) yaitu: (1) derajat Kepercayaan (credibility), teknik pencapaian kredibilitas data mengambil teknik pemeriksaan ketekunan pengamatan dan trianggulasi. Rencana kegiatan ketekunan pengamatan ini peneliti lakukan selama 3 minggu dengan mengikuti pembelajaran tematik di PAUD Melawi; (2) keteralihan (transferability), merupakan validitas eksternal. Kriteria keteralihan sebagai persoalan empiris bergantung pada kesamaan konteks pengirim dan penerima; (3) Kebergantungan (dependability), merupakan reability atau reabilitas. Pengujian dependability dilakukan dengan cara audit terhadap keseluruhan proses penelitian; dan (4) kepastian (confirmability) disebut sebagai uji objektivitas. Penelitian dikatakan objektif bila hasil penelitian telah disepakati banyak orang.

Anlisis data dalam penelitian ini menggunakan model interaktif yang terdiri dari empat komponen yang saling berhubungan yaitu pengumpulan data, reduksi data, interprestasi dan penarikan kesimpulan.

\section{HASIL DAN PEMBAHASAN}

Berdasarkan analisis hasil temuan tersebut dikatakan bahwa dalam pelaksanaan pembelajaran tematik di PAUD di Kabupaten Melawi sesuai dengan prinsip-prinsip pembelajaran tematik yaitu meliputi tema-tema yang dipilih dekat dengan kehidupan anakanak, kesederhanan tema sederhana bagi anak-anak, kemenarikan tema menarik bagi anak-anak dan isendetalan tema juga insidental sesuai dengan peristiwa yang dialami oleh anak-anak.

Tema yang paling bagus adalah tema yang memiliki kegiatan potensial serta anak dapat melakukan pengalaman pertamanya melalui kegiatan tersebut. Ketentuan jumlah tema yang dibahas tidak dapat berbeda-beda, hal tersebut sesuai dengan hasil penelitian (Hegde \& Cassidy, 2009) tentang kindergaten teachers' perspective on developmentally ap- propraite practice (DAP): A study conducted in mumbay Iindia), "Hasil dari penelitian kualitatif ini mengemukakan bahwa ada 11 tema yang digunakan dalam proses pembelajaran. Oleh karena itu banyak sedikitnya tema ditentukan oleh bagaimana keadaan anak dan kondisi sekolah. Berikut ini tema pembelajaran tematik yang dituangkan ke dalam program tahunan pada beberapa lembaga PAUD yang ada di Kabupaten Melawi yang di jadikan sebagai sasaran penelitian. Secara sederhana disajikan pada Tabel 1.

Tabel 1. Program Tahunan

\begin{tabular}{clc}
\hline No. & \multicolumn{1}{c}{ Tema } & Alokasi Waktu \\
\hline 1. & Diri Sendiri & 3 Minggu \\
2. & Lingkunganku & 4 Minggu \\
3. & Kebutuhanku & 4 Minggu \\
4. & Binatang & 3 Minggu \\
5. & Tanaman & 3 Minggu \\
6. & Rekreasi & 4 Minggu \\
7. & Pekerjaan & 3 Minggu \\
8. & Air, Api dan Udara & 2 Minggu \\
9. & Alat Komunikasi & 2 Minggu \\
10. & Tanah Airku & 3 Minggu \\
11. & Alam Semesta & 3 Minggu \\
\hline
\end{tabular}

Tema program tahunan ini yang nantinya di turunkan menjadi program semseter. Program semester ini terdiri dari rangkaian tema-tema, subtema serta alokasi waktu, pada program semester ini kita dapat menentukan kegiatan puncak tema, baik di akhir tema ataupun transisi antara tema. Penentuan tema dilaksanakan dalam agenda pertemuan awal tahun pelajaran yang dikuti oleh semua guru dan kepala sekolah. Hasil dari pertemuan ini menentukan tema yang akan digunakan selama satu tahun. Hal ini dapat diperkuat dari hasil wawancara dengan guruguru PAUD yang ada di Kabupaten Melawi mengatakan bahwa: selama ini dalam menentukan tema pembelajaran kami melakukan diskusi di awal tahun pelajaran dan di ikuti oleh semua guru dan kepala sekolah. Tema yang sudah ditentukan kemudian di buat oleh guru dalam program tahunan. Adapun rancangan program semester yang ada di lembaga PAUD Kabupaten Melawi dapat dilihat pada Tabel 2. 
JPPM (Jurnal Pendidikan dan Pemberdayaan Masyarakat), 5 (2), 2018 - 195

Kartini Kartini, Waridah Waridah

Tabel 2. Program Semester

\begin{tabular}{|c|c|c|c|}
\hline \multicolumn{4}{|c|}{ Semester 1} \\
\hline No. & Tema & Sub Tema & Alokasi Waktu \\
\hline \multirow[t]{2}{*}{1.} & Diri Sendiri & 1.1 Aku & 3 Minggu \\
\hline & & 1.2 Panca Indra & \\
\hline \multirow[t]{3}{*}{2.} & Lingkunganku & 2.1 Keluargaku & 4 Minggu \\
\hline & & 2.2 Rumah & \\
\hline & & 2.3 Sekolah & \\
\hline \multirow[t]{4}{*}{3.} & Kebutuhanku & 3.1 Makanan & 4 Minggu \\
\hline & & 3.2 Minuman & \\
\hline & & 3.3 Pakaian & \\
\hline & & 3.4 Kesehatan dan keamanan & \\
\hline \multirow[t]{2}{*}{4.} & Binatang & 4.1 Binatang di darat & 3 Minggu \\
\hline & & $\begin{array}{l}\text { 4.2 Binatang di air } \\
\text { 4.3 Binatang di udara }\end{array}$ & \\
\hline \multirow[t]{3}{*}{5.} & Tanaman & 5.1 Sayuran & 3 Minggu \\
\hline & & 5.2 Buah-buahan & \\
\hline & & 5.3 Pohon-pohon & \\
\hline \multicolumn{4}{|c|}{ Semester II } \\
\hline \multirow[t]{3}{*}{6.} & Rekreasi & 6.1 Rekreasi & 4 Minggu \\
\hline & & 6.2 Kendaraan & \\
\hline & & 6.3 Pesisiran & \\
\hline \multirow[t]{2}{*}{7.} & Pekerjaan & 7.1 Jasa & 3 Minggu \\
\hline & & 7.2 Profesi & \\
\hline \multirow[t]{2}{*}{8.} & Air, Udara dan Api & 8.1 Manfaat (air, api dan udara) & 2 Minggu \\
\hline & & 8.2 Bahaya (air, api dan udara) & \\
\hline \multirow[t]{2}{*}{9.} & Alat Komunikasi & 9.1 Audio & 2 Minggu \\
\hline & & 9.2 Visial & \\
\hline \multirow[t]{3}{*}{10.} & Tanah Airku & 10.1 Negaraku & 3 Minggu \\
\hline & & 10.2 Kehidupan di kota & \\
\hline & & 10.3 Kehidupan didesa & \\
\hline \multirow[t]{2}{*}{11.} & Alam Semesta & 11.1 Benda-benda di langit & 3 Minggu \\
\hline & & 11.2 Gejala alam & \\
\hline
\end{tabular}

Dalam program semester dibuat sebanyak dua semester yaitu semester 1 dan semester 2. Pada tiap semester minimal waktu yang harus di tempu adalah sebanyak 17 minggu, tema dibuat sendiri oleh setiap lembaga sesuai dengan prinsip pemilihan tema. Setelah kita menyusun program semester, maka kita dapat membuat rancangan pelaksanaan pembelajaran mingguan (RPPM) secara sederhana. Dalam menyusun RPPM, kita dapat menyesuaikan dengan model pembelajaran yang diterapkan oleh layanan PAUD. komponen yang perlu dicantumkan di dalam RPPM yaitu sebagai berikut: (1) identitas lembaga (Nama lembaga, semester/ tahun ajaran, bulan, minggu, kelompok usia, tema dan sub tema); (2) tema/sub tema yang telah ada pada program semester; (3) materi pembelajaran yang mengacu pada STPPA layanan sesuai dengan KD yang telah dipilih pada program semester; dan (4) rencana kegiatan. Dalam menyusun RPPM harus disesuaikan dengan model pembelajaran yang diterapkan. Adapun rencana pelaksanaan pembelajaran mingguan yang ada di lembaga PAUD Kabupaten Melawi dapat dilihat pada Gambar 1.

Setelah menyusun Rancangan Pelaksanaan Pembelajaran Mingguan barulah menyusun Rancangan Pelaksanaan Pembelajaran Mingguan (RPPH). RPPH merupakan acuan bagi guru untuk mengelola kegiatan bermain dalam satu hari, format RPPH tidak harus baku, tetapi dapat dikembangkan sesuai kreativitas, kenyamanan dan kemudahan guru. RPPH diturunkan dari Rencana Pelaksanaan Pembelajaran Mingguan (RPPM). RPPH menjadi Perencanaan yang sangat penting karena sangat mempengaruhi perencanaan pembelajaran yang lainnya. Apabila RPPH tidak dapat terlaksana dengan baik, maka sudah dapat dipastikan akan menghambat keberhasilan perencanaan pembelajaran yang lain. RPPH juga menjadi tolak 


\section{JPPM (Jurnal Pendidikan dan Pemberdayaan Masyarakat), 5 (2), 2018 - 196}

Kartini Kartini, Waridah Waridah

ukur bagi guru untuk mengembangkan kreatifitasnya dalam mengajar dan mengembangkan materi. Indikator yang terdapat di dalam $\mathrm{RPPH}$ yaitu identitas program, tujuan pembelajaran, materi pembelajaran, sumber belajar, alat dan bahan yang digunakan, dan yang paling penting di dalam RPPH terdapat kegiatan awal, inti dan penutup yang menjadi bagian terpenting dalam perencanaan pembelajaran.

\begin{tabular}{|l|}
\hline \multicolumn{1}{|c|}{ Rancangan Pelaksanaan Pembelajaran } \\
Mingguan (RPPM) PAUD Kabupaten \\
Melawi \\
Tema : Diriku \\
Sub Tema : Identitas diri/nama/jenis \\
kelamin/usia \\
Kelompok : A \\
Semester/Minggu: 1 / 1 \\
KD: 1.1, 1.2, 2.1, 2.5, 2.8. 2.12, 3.1, 4.1, 3.2, 4.2, 3.3 \\
4.3, 3.6, 4.6, 3.10, 4.10, 3.11, 4.11, 3.12, 4.12, 3.14, 4.14. \\
Muatan/Materi: \\
1.1.3. Aku diciptakan olehTuhan \\
1.2.2. Menyayangi diri sendiri \\
2.1.3. Menjaga kebersihan \\
2.5.3. Berani tampil di depan umum \\
2.8.2. Mengurus dirinya sendiri \\
2.12.2.Meminta dan memberi maaf \\
\hline
\end{tabular}

Gambar 1. Rancangan Pelaksanaan

Pembelajaran Mingguan (RPPM) PAUD Melawi

RPPH perlu mencantumkan tujuan pembelajaran. Tujuan pembelajaran merupakan salah satu aspek yang perlu dipertimbangkan dalam merencanaan pembelajaran, sebab segala kegiatan pembelajaran muaranya pada tercapainya tujuan tersebut. Sejalan dengan pendapat (Zainal, 2012, p. 55) yang mengungkapkan tujuan pembelajaran sebagai perilaku yang hendak dicapai yang dinyatakan dalam bentuk perilaku yang diwujuddkan dalam bentuk bentuk tulisan untuk menggambarkan hasil belajar yang diinginkan. Tujuan pembeljaran sudah dicantumkan. Penggunaan tujuan pembelajaran sudah baik, namun lebih baik jika guru mencantumkan tujuan yang berbeda antara sentra yang satu dengan yang lain sehingga dapat lebih tergambarkan ciri khas pada model pembelajaran dalam setiap kelas.

Adapun komponen rancangan pelaksanaan pembelajaran harian (RPPH) dapat lihihat pada Gambar 2.

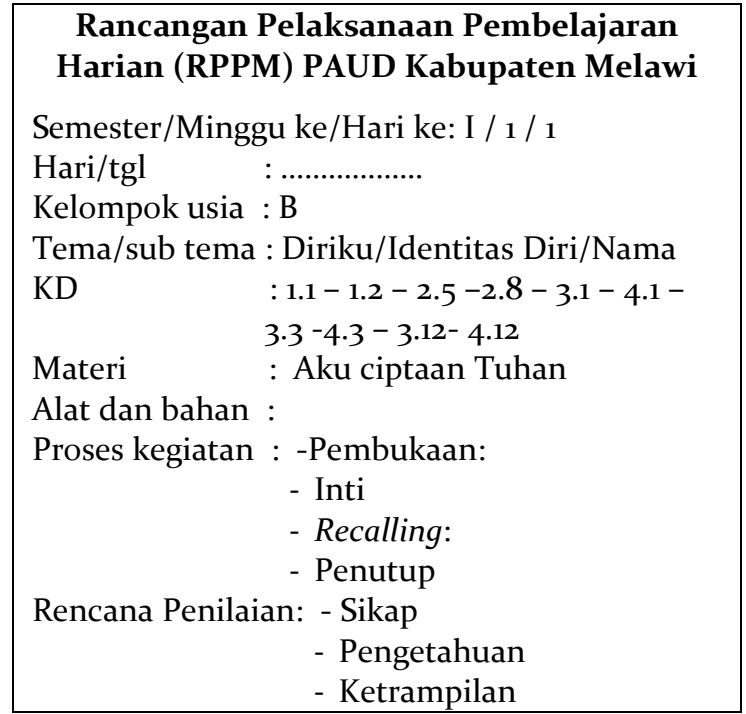

Gambar 2. Rancangan Pelaksanaan Pembelajaran Harian (RPPH) PAUD Melawi

Berdasarkan tahap-tahap rancangan pembelajaran yang ada di PAUD Kabupaten Melawi sudah sesuai dengan aturan Departemen Pendidikan Nasional Republik Indonesia tentang standar kurikulum PAUD. Hal ini sejalan dengan hasil penelitian (Fitri, 2017) yang menyatakan bahwa perencanaan pembelajaran Kurikulum 2013 pendidikan anak usia dini di PAUD IT Auladuna Kota Bengkulu sudah baik karena sudah mengacu STPPA, kelompok usia anak, Kompetensi Inti (KI), dan Kompetensi Dasar (KD). Program semester yang terdiri dari tema, subtema, alokasi waktu, Kompetensi Dasar, materi pelajaran, dan aspek-aspek perkembangan sudah baik. Rencana Pelaksanaan Pembelajaran Mingguan (RPPM) sudah baik karena sudah mencantumkan identitas program, kompetensi dasar dan kegiatan pembelajaran yang dilakukan selama satu minggu. Rencana Pelaksanaan Pembelajaran Harian (RPPH) sudah baik karena sudah mencantumkan identitas program, tujuan pembelajaran, materi pembelajaran, alat dan bahan yang disesuaikan dengan tema, dan kegiatan belajar mengajar selama satu minggu. Perencanaan penilaian dalam kategori cukup dan sudah mencantumkan penilaian dan waktu penilaian.

Hasil penelitian yang diperoleh sudah dapat mendiskripsikan perencanaan pembelajaran Kurikulum 2013 di PAUD yang ada di Kabupaten Melawi. Perencanaan Pembelajaran PAUD terdiri dari Program Tahunan, 
Program Semester, Rencana Pelaksanaan Pembelajaran Mingguan, Rencana Pelaksanaan Pembelajaran Harian, dan Penilaian sebagian besar sudah direncanakan dengan sangat baik tanpa keluar dari peraturan yang sudah ditetapkan oleh Kurikulum 2013.

Pada pelaksanaannya tema dan kompetensi dasar dikembangkan menjadi muatan pembelajaran. Muatan pembelajaran adalah cakupan materi yang ada pada kompetensi dasar sebagai bahan yang akan dijadikan kegiatan-kegiatan untuk mencapai kompentensi sikap spiritual, sikap sosial, pengetahuan, dan keterampilan. Prinsip-prinsip dalam pemilihan tema sebagai berikut: (a) Kedekatan tema hendaknya dipilih mulai dari halhal yang terdekat dengan kehidupan anak. Dekat dimaksud dapat dekat secara fisik dan juga dekat secara emosi atau minat anak. Tema yang terdekat secara fisik dengan anak, misalnya diri sendiri, keluarga, lingkungan rumah, lingkungan sekolah, binatang, tanaman, dan lingkungan alam. Setiap lembaga tentu memiliki kondisi yang berbeda-beda, misalnya bagi lembaga PAUD yang lingkungannya dekat dengan pantai, maka tema lingkunganku dengan subtema "pantaiku yang indah" dapat menjadi pilihan tema sesuai dengan prinsip kedekatan. (b) Kesederhanaan Tema yang dipilih yang sudah dikenal anak agar anak mudah memahami pokok bahasan dan dapat menggali lebih banyak pengalamannya. Contoh Berdasarkan prinsip kesederhanaan kita dapat memilih tema "binatang" dengan subtema "Ayam" melalui sub-subtema yang sederhana kepada peserta didik; (c) Kemenarikan tema yang dipilih harus menarik bagi anak dan mampu menarik minat belajar anak. Untuk lebih memberikan kemenarikan minat belajar anak dan kebermaknaan suatu tema, hendaknya guru dapat merumuskan tema dalam bentuk kalimat yang inspiratif, misalkan tema "mata-hari" dirumuskan dengan "matahari sumber kehidupan manusia", tema "tanaman" dirumuskan menjadi "menanam dan merawat tanaman", tema "binatang" dirumuskan menjadi "menyayangi binatang piaraan" Dalam memilih tema yang menarik bagi anak, guru dapat melakukan pengamatan terhadap halhal yang dekat dengan anak baik secara fisik maupun emosional anak, misalnya dengan melakukan curah gagasan dengan anak apa yang anak sukai; (d) Keinsidentalan pemilihan tema tidak selalu yang direncanakan di awal tahun, dapat juga menyisipkan kejadian luar biasa yang dialami anak, misalnya peristiwa banjir yang dialami anak dapat dijadikan tema insidental menggantikan tema yang sudah direncanakan sebelumnya.

Adapun langkah-langkah pelaksanaan pembelajaran tematik setiap hari dilakukan dengan menggunakan tiga tahapan kegiatan yaitu; (1) kegiatan pembukaan awal/pendahuluan, bisanya diawali dengan enyambutan anak yang dilakukan oleh dua guru secara bergantian sesuai jadwal yang telah ditentukan oleh sekolah. Guru yang bertugas sebagai petugas penyambutan bertugas menyambut anak kemudian mengarahkan anak agar memasuki kelas untuk menaruh tas. Sementara guru yang lain menyiapkan bahan ajar serta media-media yang akan digunakan dalam proses pembelajaran yang akan berlangsung. Dikarenakan lembaga PAUD di Kabupaten Melawi yang di jadikan sasaran penelitian rata-rata menggunakan pendekatan kelompok yang di bagi menjadi 3 kelompok jadi guru harus menyiapkan 3 jenis kegiatan pembelajaran serta menyediakan alat penilaian yang telah ditentukan. Tujuan kegiatan pembuka ini untuk membangkitkan motivasi dan memfokuskan perhatian peserta didik untuk berpartisipasi aktif dalam proses pembelajaran. Memfokuskan perhatian anak dapat dilakukan dengan menggunakan gambar, alat peraga, mendengarkan cerita baru yang menimbulkan pertanyaan dengan catatan cerita tersebut ada hubungan dengan materi yang akan dibahas guru perlu membangkitkan perhatian dan motivasi anak sebelum kegiatan berlanjut pada kegiatan inti, biasanya pikiran anak masih teringat pada materi pelajaran yang dibahas sebelumnya; (2) kegiatan inti, dilaksanakan sebelum anak-anak bermain di luar ruangan. Pembelajaran inti pelaksanaan pembelajaran sesuai dengan tema-tema yang telah ditentukan. Tema yang sudah ditentukan kemudian di rincikan kedalam sub tema dan di rincikan ke dalam su-sub tema pembelajaran. Pembelajaran inti dilakukan dari pukul 07.30-09.00 WIB. Pembelajaran inti dimulai dengan kegiatan awal yaitu dengan 
JPPM (Jurnal Pendidikan dan Pemberdayaan Masyarakat), 5 (2), 2018 - 198

Kartini Kartini, Waridah Waridah

salam, do'a mau belajar, saling sapa dengan anak kemudian dilanjutkan dengan tanya jawab tema pembelajaran yang akan dilakukan. Kegiatan bermain di luar ruangan bertujuan untuk menstimulasi aktivitas fisikmotorik anak dan membuang energi negatif yang ada pada anak. Setelah kegiatan belajar didalam kelas, kemudian guru mengarahkan anak-anak untuk keluar kelas mengikuti kegiatan bermain diluar ruangan. Adapun jenis kegiatan bermain diluar ruangan yang dilakukan di Lembaga PAUD Kabupaten Melawi yang menjadi sasaran penelitian antara lain anak bermain perosotan, anak bermain ayunan, anak bermain papan jungkit. Kegiatan bermain di luar ruangan dilaksanakan dari pukul 09.30 WIB sekaligus sebagai jam istirahat. Kegiatan istirahat dilakukan pada pukul 09.00-09.30 WIB namun sebelum keluar anak makan bersama dengan temantemanya. Kegiatan makan bersama dimulai dengan berdo'a yang dipimpin oleh salah satu anak secara bergiliran dan diakhiri dengan do'a yang dipimpin oleh salah satu anak. kegiatan inti merupakan proses pencapaian kompetensi dasar, kegiatan pembelajaran yang dilakukan secara atraktif, inspiratif, menyenangkan, manantang, memotivasi peserta didik untuk berpartisipasi aktif, serta memberikan ruang yang cukup bagi prekarsam kreativitas, dan kemandirian sesuai dengan bakat, minat, dan perkembangan fisik, serta psikologis peserta didik (Rosdiani, 2013, p. 103); dan (3) kegiatan penutup. Kegiatan penutup merupakan akhir dari kegiatan belajar mengajar yang sudah dilakukan selama satu hari. Kegiatan penutup merupakan kegiatan yang dilakukan untuk mengakhiri aktivitas pembelajaran yang dapat dilakukan dalam bentuk rangkuman atau kesimpulan, penilaian, dan refleksi, umpan balik serta tindak lanjut. Kegiatan yang dilakukan pada kegiatan penutup seperti menanyakan perasaan anak, berdiskusi kegiatan main apa saja yang sudah dimaikan, pemberian tugas kepada anak untuk dilakukan dirumah, bercerita pendek berisi pesanpesan, menginformasikan kegiatan untuk esok hari, dan berdoa. Selanjutnya kegiatan akhir guru menanyakan kepada anak terkait dengan pembelajaran yang telah dilakukan selama satu hari. Selanjutnya kegiatan pengaman kegiatan yang dilakukan anak sambil menunggu penjemputan dari orang tua. Anak bermain di tempat yang sudah disetting oleh guru yang bertujuan untuk penjagaan anak sampai menunggu penjemputan dari orang tua. Dengan demikian, sifat dari kegiatan penutup adalah untuk menenangkan.

Penilaian Kurikulum 2013 Pendidikan Anak Usia Dini rata-rata sudah cukup baik. Penilaian membutuhkan perencanaan yang matang agar guru tidak salah dalam menilaian anak didik. Berdasarkan penilaian tersebut, pendidik dan orang tua anak dapat memperoleh informasi tentang capaian perkembangan untuk menggambarkan sikap, pengetahuan, dan keterampilan yang dimiliki anak setelah melakukan kegiatan belajar. Penilian menggunakan Teknik penilaian yang membuat penilaian menjadi lebih terarah. Teknik penilaian digunakan dalam menilai peserta didik. Teknik penilaian yang digunakan adalah portofolio, observasi, unjuk kerja, catatan anekdot, dan hasil karya anak.

Kurikulum 2013 Pendidikan Anak Usia Dini, tema tidak ditetapkan oleh pemerintah, tetapi bersifat fleksibel penetapannya oleh lembaga PAUD yang melibatkan seluruh guru pada saat pemilihan dan penetapannya. Banyak hal di lingkungan kehidupan yang dapat dijadikan tema. Artinya, apa yang terdapat di lingkungan terdekat seperti air, batu, kelapa, alat transportasi, laut, dan lainlainnya dapat diangkat menjadi tema. Oleh karenan itu, pengembangan tema di setiap lembaga dapat berbeda-beda sesuai dengan lingkungan lembaga tersebut serta kondisi sarana dan prasarananya. Kurikulum 2013 Pendidikan Anak Usia Dini (PAUD) mencakup pengembangan pada aspek struktur kurikulum, proses pembelajaran dengan pendekatan saintifik, dan penilaian yang bersifat autentik. Kurikulum 2013 mengusung pengembangan pembelajaran konstruktivisme yang lebih bersifat fleksibel dalam pelaksanaan sehingga memberi ruang pada anak untuk mengembangkan potensi dan bakatnya.

Berdasarkan analisis hasil temuan di atas dikatakan bahwa dalam pelaksanaan pembelajaran tematik pada pendidikan anak usia dini di Kabupaten Melawi sesuai dengan 


\title{
JPPM (Jurnal Pendidikan dan Pemberdayaan Masyarakat), 5 (2), 2018 - 199
}

\author{
Kartini Kartini, Waridah Waridah
}

prinsip-prinsip pembelajaran tematik hal ini sejalan dengan pendapat (Mustofa, Soendjodjo, Susanti, Nurmiati, \& Yuliantina, 2015) yang menyatakan bahwa Kurikulum 2013 Pendidikan Anak Usia Dini menggunakan pembelajaran tematik. Keberhasilan proses pembelajaran tematik dipengaruhi oleh 3 faktor yaitu perencanaan, pelaksanan dan penilaian. Tahapan pelaksanaan pembelajaran tematik di PAUD dimulai dengan adanya identifikasi tema yang akan digunakan dalam pembelajaran. Tema yang sudah ditentukan dianalisis dengan kemampuan dasar yang akan dikembangkan dalam proses pembelajaran. Perencanaan yang dibuat dituangkan ke dalam Rencana Pelaksanaan Pembelajaran Mingguan (RPPM) dan Rencana Pelaksanaan Pembelajaran Harian (RPPH). Setiap RPPM mengacu dari program semester yang telah dibuat. Rencana Pelaksanaan Pembelajaran Harian (RPPH) dikembangkan secara rinci dari RPPM yang memuat tema tertentu dari program semster. Rancangan pelaksanaan pembelajran harian disusun berdasarkan tema/subtema atau KD yang dilaksanakan dalam satu atau lebih pertemuan.

Berdasarkan hasil wawancara dengan guru kelas dan kepala sekolah/Pengelola PAUD yang ada di Kabupaten Melawi menyatakan bahwa Rancangan Pelaksanaan Pembelajaran Harian dibuat guru secara mandiri, namun sebelumnya guru telah menerima pelatihan serta diskusi dengan teman sejawat antar guru untuk penyusunan Rancangan Pelaksanaan Pembelajran Harian yang baik. Hasil triangulasi wawancara dengan Kepala PAUD di Kabupaten Melawi yang dijadikan sasaran penelitian juga menjelaskan Rancangan Pelaksanaan Pembelajran Harian disusun oleh guru itu sendiri atau disusun secara mandiri. Dalam sebuah rencana pelaksanaan pembelajaran harian dapat memuat berbagai informasi mengenai pembelajaran yang akan dilaksanakan, diantaranya kompetensi dasar, langkah kegiatan, media dan sumber belajar, indikator pencapaian pembelajaran dan hasil penilaian. Pendekatan/ metode pembelajaran, pengelolaan dalam pelaksanaan kegiatan pembelajaran. Berdasarkan hasil penelitian didapati guru sudah menyusun tujuan pembelajaran yang akan dicapai, pendekatan atau metode pembel- ajaran yang akan digunakan sudah terdapat pada Rancangan Pelaksanaan Pembelajran Harian yang dibuat guru.

Proses penilaian pembelajaran tematik yang dilakukan di PAUD yang ada di kabupaten melawi merupakan proses yang berkelanjutan dan berkesinambungan, ini bertujuan agar hasil dari informasi penilaian dapat digunakan dan bermanfaat untuk membuat alternatif-alternatif untuk mengambil keputusan (Purwanto, 1984, P.40). Informasi penilaian digunakan untuk melihat hasil perkembangan anak dan akan disampaikan kepada orang tua anak melalui buku penghubung yang setiap hari di catat oleh pendidik.

Tujuan asesment perkembangan anak usia dini, antara lain untuk: (1) mendeteksi perkembangan dan arahan dalam melakukan penilaian diagnostik ketika terindikasi, yang meliputi deteksi tentang status kesehatan anak usia dini, kepekaan indera, bahasa, motorik kasar, motorik halus, dan perkembangan sosial-emosional, (2) mengidentifikasi minat dan kebutuhan anak usia dini, (3) menggambarkan kemajuan perkembangan dan belajar anak usia dini, (4) mengembangkan kurikulum, (5) memperbaiki dan mengembangkan kegiatan pembelajaran yang sesuai dengan perkembangan dan kebutuhan anak usia dini, dan (6) mengasesmen program dan lembaga (akuntabilitas program dan lembaga).

Penilaian yang digunakan dalam pembelajaran tematik di PAUD Kabupaten Melawi Kecamatn Nanga Pinoh yaitu dengan hasil karya, tugas projek, dan observasi. Observasi adalah cara pengumpulan data untuk mendapatkan informasi melalui pengamatan langsung terhadap sikap dan perilaku peserta didik, yang mengacu pada indikator yang telah di tetapkan. Aspek yang di observasi serta hasilnya bervariasi, berdasarkan pada tujuan penilaian. Obervasi dilakukan oleh guru pada saat proses pembelajaran berlangsung. Pada saat observasi guru juga menggunakan lembar cheklist bagi anak yang telah tercapai aspek perkembangannya (skala capaian Perkembangan anak). Selain observasi, guru juga menggunakan Anecdotal record atau catatan anekdot merupakan kumpulan catatan peristiwa-peristiwa penting 
tentang sikap dan perilaku peserta didik dalam situasi tertentu. Anekdot merupakan perkembangan penting yang dimunculkan anak pada saat bermain. Catatan ini dilakukan guru pada saat proses pembelajaran dan saat anak bermain. Catatan khusus anak ini ditulis oleh guru secara uraian, objektif dan faktual apa adanya, serta tidak menggunakan interpretasi dan asumsi dari guru pribadi akan tetapi berdasarkan pada pengamatan guru selama anak di PAUD. Dengan demikian implemntasi pembelajaran tematik pada anak usia dini di Kabupaten Melawi di katakan sudah sangat baik, dimana implementasinya sudah mengikuti aturan yang ditetapkan pemerintah. Namun hanya ada 1 PAUD yang dijadikan sasaran penelitian masih tidak sesuai dengan prinsip pembelajaran tematik. Dimana PAUD tersebut rancangan pembelajaran sudah mengikuti prinsip pembelajaran tematik namun ditemukan ketika pelaksanaan atau proses pembelajaran berlangsung tidak sesuai dengan rancangan pembelajaran yang telah dibuat dengan yang diterapkan, dimana lembaga PAUD tersebut menerapkan calistung saja. Hal ini dikarenakan oleh tuntutan orang tua yang menginginkan anaknya mendapatkan pembelajaran menghitung dan menulis saja, sehingga mau tidak mau guru yang ada di PAUD tersebut mengikuti keinginan dari orang tua murid tersebut. Namun dibeberapa PAUD di Kabupaten Melawi sudah menerapkan pembelajaran tematik dengan sangat baik.

\section{SIMPULAN}

Berdasarkan hasil penelitian dan pembahasan yang sudah dilakukan, peneliti memperoleh kesimpulan bahwa implementtasi pembelajaran tematik pada Pendidikan Anak Usia Dini di Kabupaten Melawi sudah mengikuti prinsip-prinsip pembelajaran tematik, hal tersebut dapat dilihat dari beberapa kegiatan yang sudah dilaksanakan yaitu sebagai berikut: Pertama, Perencanaan pembelajaran tematik di PAUD Kabuapten Melawi dimulai dengan penentuan tema yang dilakukan oleh semua guru diawal tahun pelajaran untuk menentukan tema-tema yang dipilih untuk satu tahun. Tema yang dipilih dibuat kedalam RPPM dan kemudian dituangkan ke dalam RPPH. Selain itu setiap Kepala Sekolah PAUD yang ada di kabupaten melawi melakukan evalusi terhadap perencanaan pembelajaran yang dibuat guru. Kedua, Pelaksanaan pembelajaran tematik di PAUD Kabupaten Melawi sesuai dengan prinsip-prinsip pembelajaran tematik yaitu kedekatan tema dengan kehidupan anak, kemenarikan tema menarik bagi anak, kesederhanaan tema sederhana bagi anak dan tema isendental dalam pembelajaran. Selain itu juga dapat dilihat pada proses pembelajaran yang meliputi, kegiatan awal, kegiatan inti dan kegiatan penutup pada saat proses pembelajaran berlangsung. Ketiga, Penilaian pembelajaran tematik di PAUD Kabupaten Melawi menggunakan penilaian percakapan, observasi, penugasan project, hasil karya anak, skala capaian perkembangan anak dan catatan anekdot ini dilakukan secara rutin agar orang tua mengetahui perilaku anak yang tidak biasa dan tidak hanya sekedar menjadi formalitas.

\section{DAFTAR PUSTAKA}

\section{Essa, E. (2011). Introduction to early childhood education. Wadsworth/Cengage Learning.}

Fitri, A. (2017). Perencanaan pembelajaran Kurikulum 2013 pendidikan anak usia dini. Jurnal Ilmiah POTENSIA, 2(1), 1-13. https://doi.org/10.33369/JIP.2.1

Hegde, A. V, \& Cassidy, D. J. (2009). Kindergarten teachers' perspectives on developmentally appropriate practices (DAP): A study conducted in Mumbai (India). Journal of Research in Childhood Education, 23(3), 367-381.

Idrus, M. (2009). Metode penelitian ilmu sosial. Yogyakarta: Erlangga.

Machali, I. (2014). Kebijakan perubahan kurikulum 2013 dalam menyongsong Indonesia emas tahun 2045. Jurnal Pendidikan Islam, 3(1), 71-94.

Merriam, S. B., \& Tisdell, E. J. (2015). Qualitative research: A guide to design and implementation. John Wiley \& Sons.

Moleong, L. J. (2013). Metodologi penelitian kualitatif (Ed. Rev.). Bandung: PT 
JPPM (Jurnal Pendidikan dan Pemberdayaan Masyarakat), 5 (2), 2018 - 201 Kartini Kartini, Waridah Waridah

Remaja https://doi.org/2010

Mustofa, D., Soendjodjo, R. P., Susanti, A., Nurmiati, N., \& Yuliantina, I. (2015). Pengembangan tema pembelajaran pendidikan anak usia dini. Jakarta: Direktorat Pembinaan Pendidikan Anak Usia Dini.

Presiden Republik Indonesia. UndangUndang Republik Indonesia nomor 20 tahun 2003 tentang sistem pendidikan nasional, Pub. L. No. 20, UndangUndang Republik Indonesia 26 (2003). Indonesia.

Rosdiani,

D. (2013). Perencanaan

pembelajaran dalam pendidikan jasmani dan kesehatan. Bandung: Alfabeta.

Sari, A., Baharuddin, B., \& Sasmiati, S. (2015). Pemahaman guru dalam pembelajaran tematik anak usia dini. Jurnal Pendidikan Anak, 1(6). Retrieved from http://jurnal.fkip.unila.ac.id/index.php /PAUD/article/view/10751

Sugiyono. (2015). Metode penelitian pendidikan: Pendekatan kuantitatif, kualitatif, dan $R \quad \mathcal{E} \quad D$. Bandung: Alfabeta.

Zainal, A. (2012). Perencanaan pembelajaran. Yogyakarta: T Pustaka Insan Mandiri. 